\title{
Peritonitis complicating continuous ambulatory peritoneal dialysis in Nottingham 1983-1988
}

\author{
M. H. WILCOX, R. G. FINCH,† R. P. BURDEN $¥$ and A. G. MORGAN $\ddagger$ \\ Departments of "†Microbial Diseases and $¥$ Renal Medicine, The City Hospital, Nottingham NG5 1 PB and $†$ Department \\ of Microbiology, The University of Nottingham, Nottingham NG7 $2 U H$
}

\begin{abstract}
Summary. During the period 1983-1988 the incidence of peritonitis in patients undergoing continuous ambulatory peritoneal dialysis (CAPD) in Nottingham fell from 2.0 to 1.2 episodes/patient/year. Cefuroxime, given intraperitoneally for 10 days, as recommended in published guidelines, failed to cure $35 \%$ of episodes of peritonitis, although only $7 \%$ of the pathogens responsible for these episodes were resistant in vitro. Cefuroxime is probably no longer appropriate as first line treatment of CAPD peritonitis.
\end{abstract}

\section{Introduction}

Continuous ambulatory peritoneal dialysis (CAPD) is the method used to manage end-stage renal failure in about one quarter of the patients undergoing dialysis in the UK. ${ }^{1}$ Staff at the Department of Renal Medicine at the City Hospital, Nottingham (CHN), serving a population of approximately one million people, began to treat patients by CAPD in 1979. In an earlier report $^{2}$ the 3-year actuarial survival for CAPD patients was $69 \%$ and technique survival was $41 \%$.

The commonest cause of CAPD failure is recurrent peritonitis which increases considerably the morbidity and cost of the procedure. To study this problem further, microbiological data relating to patients treated in Nottingham by CAPD during the period 1983-1988 have been collected prospectively and have been examined to review CAPD-associated peritonitis, with particular emphasis on its aetiology, the antibiotic sensitivity of bacteria causing it and the efficacy of treatment. The study period includes more than 400 patient years of CAPD (the largest UK experience reported to date), during which treatment of peritonitis has followed recommended guidelines. ${ }^{3}$

\section{Subject and methods}

All patients (297 in total) were trained in a generally similar way by a specialist CAPD nursing team. Most patients used the Travenol "Luer lock system II", although since October 1987 the Travenol "Freeline Disconnect" system was introduced gradually; $10 \%$ and $40 \%$ of patients were using the "Freeline Discon-

Received 23 Jan. 1990; accepted 17 July 1990.

- Present address: Department of Experimental and Clinical Microbiology, University of Sheffield Medical School, Beech Hill Road, Sheffield S10 2RX. nect" system at the end of 1987 and 1988, respectively. Double cuff silastic Tenckhoff catheters were inserted through the anterior abdominal wall under local anaesthesia, unless (as in less than $5 \%$ of all cases) abdominal scarring necessitated insertion under general anaesthesia.

Patients receiving CAPD were instructed to attend hospital as soon as possible if they developed symptoms or signs of peritonitis (abdominal pain, fever, cloudy dialysate). The peritoneal cavity was drained completely before antibiotic treatment was begun and the full bag of used dialysate was sent to the Microbiology Department. The dialysate was cultured by inoculating $20 \mathrm{ml}$ aseptically into each of two blood-culture bottles. ${ }^{4}$ These were incubated for up to 7 days at $37^{\circ} \mathrm{C}$. Subcultures were made if there was visible growth or turbidity, or otherwise on the seventh day of incubation. The white cells in a further $20 \mathrm{ml}$ of dialysate were lysed by adding Triton-X, and, after centrifugation, the resulting deposit was cultured at $37^{\circ} \mathrm{C}$ aerobically and anaerobically on blood agar. ${ }^{5}$ Red and white blood cells in the dialysate were counted in a Neubauer chamber. The bacteria isolated were identified by standard microbiological methods ${ }^{6}$ and, in the case of coagulase-negative staphylococci, were assigned to species by examination with the APISTAPH system (API, Basingstoke). Antibiotic sensitivity testing was performed by an agar incorporation "breakpoint" method. ${ }^{7}$ The antibiotics and the breakpoints used to characterise fully sensitive or resistant strains included cefuroxime ( 8 and $32 \mathrm{mg} / \mathrm{L}$ ); gentamicin $(0.5$ and $2 \mathrm{mg} / \mathrm{L}$ for staphylococci and 4 and $8 \mathrm{mg} / \mathrm{L}$ for coliforms) and ceftazidime ( 2 and $16 \mathrm{mg} /$ L). Sensitivity to vancomycin was tested by a diskdiffusion method, ${ }^{8}$ the disks containing $5 \mu \mathrm{g}$. When analysing results, strains recorded as of "reduced sensitivity" were considered to be resistant, i.e., strains whose growth was inhibited by the higher but not the lower antibiotic breakpoint concentration, or those 
for which the inhibition zone size was reduced relative to the control (the "Oxford" staphylococcus, strain NTCC 6571).

Peritonitis was considered to be present if dialysis fluid contained bacteria or if the neutrophil count exceeded 100 cells $/ \mu$ l. $^{3}$ Peritonitis was treated with intra-peritoneal cefuroxime at a concentration of $125 \mathrm{mg} / \mathrm{L}$ of dialysis fluid given for 10 days. $^{3}$ Treatment efficacy was assessed by clinical and microbiological response in patients receiving antibiotics for at least 10 days, the recommended treatment period. ${ }^{3}$ Failure was defined as the isolation of the same organism, or the persistence of symptoms, in association with a raised dialysate neutrophil count, within 2 weeks of stopping antibiotic treatment. ${ }^{3}$ Treatment with cefuroxime was stopped if the patient failed to respond, or if microbiological information showed it to be inappropriate. Rarely (i.e., in less than $10 \%$ of episodes), other antibiotics were given first if previous culture data suggested that a specific pathogen was likely to be present; for example gentamicin (4-8 $\mathrm{mg} / \mathrm{L}$ of dialysis fluid) if pseudomonal peritonitis was probable. Vancomycin $50 \mathrm{mg} / \mathrm{L}$ was the commonest substitute for cefuroxime, but was given in less than $6 \%$ of episodes, to patients with infections caused by staphylococci, streptococci (including enterococci), or "diphtheroids".

\section{Results}

The pathogens that caused peritonitis are listed in table I; coagulase-negative staphylococci (CNS) were commonest; Staphylococcus epidermidis sensu strictu accounting for $75 \%$ of this group. Altogether, 26 species groups were identified, but six accounted for $81 \%$ of all episodes of peritonitis: CNS, S. aureus, viridans streptococci, Escherichia coli, Klebsiella spp. and Pseudomonas spp. The culture failure rate fell from $15 \%$ to $5 \%$ (mean $10 \%$ ) during the study.

Table II shows the annual incidence of peritonitis. This remained at about one infection in every 6-8 months of patient treatment, until 1988 when the mean infection-free period increased to 10 months. The number of episodes of peritonitis rose in 1987, reflecting an increase in the number of new patients starting CAPD during this year. Almost half of all patients experiencing peritonitis in each year (mean $49 \%$, range $43-53 \%$ ) had at least two episodes, and $22 \%$ (range $20-24 \%$ ) had three or more.

The antibiotic sensitivities of the pathogens isolated are shown in table III. All gram-positive bacteria isolated were sensitive to vancomycin and all gramnegative bacteria were sensitive to gentamicin. On average, $15 \%$ of all isolates were resistant to cefuroxime and $27 \%$ to gentamicin during the study. Cefuroxime

Table I. Micro-organisms causing CAPD peritonitis in Nottingham 1983-1988

\begin{tabular}{|c|c|c|c|c|c|c|}
\hline \multirow[b]{2}{*}{ Species } & \multicolumn{6}{|c|}{ Number $(\%)$ of isolates in } \\
\hline & 1983 & 1984 & 1985 & 1986 & 1987 & 1988 \\
\hline \multirow{7}{*}{$\begin{array}{l}\text { CNS } \\
\text { S. aureus } \\
\text { Viridans streptococci } \\
\text { Enterococcus spp. } \\
\text { Micrococcus spp. } \\
\beta \text {-haemolytic streptococ- } \\
\text { cus (group F) } \\
\text { Str. pneumoniae }\end{array}$} & $37(43)$ & $43(45)$ & $38(37)$ & $56(51)$ & $82(57)$ & $58(53)$ \\
\hline & $3(3)$ & $10(10)$ & $17(17)$ & $11(10)$ & $19(13)$ & 21(19) \\
\hline & $10(11)$ & $1(1)$ & $7(7)$ & $6(5)$ & $5(3)$ & $1(1)$ \\
\hline & $4(5)$ & $\ldots$ & $2(2)$ & $3(3)$ & $1(1)$ & $\ldots$ \\
\hline & $\ldots$ & $\ldots$ & $1(1)$ & $\ldots$ & $1(1)$ & $\ldots$ \\
\hline & $\cdots$ & $\cdots$ & $1(1)$ & $\cdots$ & $\ldots$ & $\cdots$ \\
\hline & $1(1)$ & $\cdots$ & $\cdots$ & $\cdots$ & $\cdots$ & $\ldots$ \\
\hline \multirow{5}{*}{$\begin{array}{l}\text { Neisseria spp. } \\
\text { “Diphtheroids" } \\
\text { Lactobacillus spp. } \\
\text { Bacillus spp. } \\
\text { Clostridium perfringens }\end{array}$} & $\cdots$ & $\ldots$ & $\cdots$ & $\cdots$ & $1(1)$ & $\cdots$ \\
\hline & $\ldots$ & $3(3)$ & $3(3)$ & $7(6)$ & $5(3)$ & $7(6)$ \\
\hline & $1(1)$ & $\ldots$ & $\ldots$ & $\ldots$ & $\ldots$ & $\ldots$ \\
\hline & $\ldots$ & $\ldots$ & $1(1)$ & $1(1)$ & $\ldots$ & $\ldots$ \\
\hline & $1(1)$ & $\cdots$ & $\cdots$ & $\cdots$ & $\ldots$ & $\ldots$ \\
\hline \multirow{11}{*}{$\begin{array}{l}\text { E. coli } \\
\text { Klebsiella spp. } \\
\text { Pseudomonas spp. } \\
\text { Proteus vulgaris } \\
\text { P. mirabilis } \\
\text { Acinetobacter spp. } \\
\text { Enterobacter spp. } \\
\text { Citrobacter spp. } \\
\text { Serratia marcescens } \\
\text { Alkaligenes } \mathrm{spp} . \\
\text { Achromobacter spp. }\end{array}$} & $5(6)$ & $6(6)$ & $6(6)$ & $5(5)$ & $5(3)$ & $5(5)$ \\
\hline & $5(6)$ & $3(3)$ & 4(4) & $1(1)$ & $8(6)$ & 4(4) \\
\hline & $3(3)$ & $13(14)$ & $13(13)$ & $8(7)$ & $8(6)$ & $2(2)$ \\
\hline & $\ldots$ & $1(1)$ & ... & $\ldots$ & $\ldots$ & $\ldots$ \\
\hline & $1(1)$ & $1(1)$ & $3(3)$ & $1(1)$ & $1(1)$ & 1(1) \\
\hline & $\ldots$ & $7(7)$ & $5(5)$ & $3(3)$ & $6(4)$ & $3(3)$ \\
\hline & $3(3)$ & $2(2)$ & $\ldots$ & $1(1)$ & $1(1)$ & $1(1)$ \\
\hline & $1(1)$ & $1(1)$ & $1(1)$ & $\ldots$ & $1(1)$ & $1(1)$ \\
\hline & $2(2)$ & $\ldots$ & $\ldots$ & $\ldots$ & $\ldots$ & $\ldots$ \\
\hline & $1(1)$ & $\ldots$ & $\ldots$ & $1(1)$ & $2(2)$ & $\ldots$ \\
\hline & $\cdots$ & $\cdots$ & $2(2)$ & $\cdots$ & $\cdots$ & $\cdots$ \\
\hline \multirow{3}{*}{$\begin{array}{l}\text { Candida spp. } \\
\text { Rhodotorula spp. } \\
\text { Torulopsis spp. }\end{array}$} & $4(5)$ & $2(2)$ & $\ldots$ & $2(2)$ & $1(1)$ & $\ldots$ \\
\hline & $\ldots$ & $1(1)$ & $\ldots$ & $\ldots$ & ... & $\ldots$ \\
\hline & $1(1)$ & $\ldots$ & $\ldots$ & $\ldots$ & $\ldots$ & $\ldots$ \\
\hline Mixed organisms & 9 & 7 & 7 & 4 & 11 & $\ldots$ \\
\hline No growth & $13(15)$ & $12(13)$ & $9(9)$ & $8(7)$ & $11(8)$ & $5(5)$ \\
\hline Total & 87 & 96 & 103 & 110 & 143 & 109 \\
\hline
\end{tabular}


Table II. Incidence of peritonitis episodes

\begin{tabular}{lccccc}
\hline Year & $\begin{array}{c}\text { Number of } \\
\text { patients* on } \\
\text { CAPD }\end{array}$ & $\begin{array}{c}\text { Total patient } \\
\text { years on CAPD }\end{array}$ & $\begin{array}{c}\text { Number (\%) of } \\
\text { patients with } \\
\text { peritonitis }\end{array}$ & $\begin{array}{c}\text { Total number } \\
\text { of peritonitis } \\
\text { episodes }\end{array}$ & $\begin{array}{c}\text { Mean number of } \\
\text { peritonitis episodes } \\
\text { per patient year }\end{array}$ \\
\hline 1983 & 50 & 42.9 & $49(98)$ & 87 & $2 \cdot 0$ \\
1984 & 71 & 57.8 & $54(76)$ & 96 & $1 \cdot 7$ \\
1985 & 84 & 65.3 & $55(65)$ & 103 & $1 \cdot 6$ \\
1986 & 86 & 74.4 & $59(69)$ & 110 & $1 \cdot 5$ \\
1987 & 87 & 85.6 & $78(90)$ & 143 & $1 \cdot 7$ \\
1988 & 94 & 90.6 & $61(65)$ & 109 & $1 \cdot 2$ \\
\hline
\end{tabular}

* Mean of patient totals in June and December.

Table III. Antibiotic resistance in isolates causing CAPD peritonitis

\begin{tabular}{|c|c|c|c|c|c|c|c|}
\hline \multirow[b]{2}{*}{ Year } & \multicolumn{3}{|c|}{$\begin{array}{l}\text { Number (\%) of gram-positive } \\
\text { isolates resistant to }\end{array}$} & \multicolumn{2}{|c|}{$\begin{array}{l}\text { Number }(\%) \text { of gram- } \\
\text { negative isolates resistant to }\end{array}$} & \multicolumn{2}{|c|}{$\begin{array}{l}\text { Total number (\%) of } \\
\text { isolates resistant to }\end{array}$} \\
\hline & CXM & VANC & GENT & CXM & GENT & CXM & GENT \\
\hline 1983 & $4(7)$ & 0 & $24(42)$ & $4(19)$ & 0 & $8(10)$ & $24(31)$ \\
\hline 1984 & $4(7)$ & 0 & $19(33)$ & $12(35)$ & 0 & $16(18)$ & 19(23) \\
\hline 1985 & $7(10)$ & 0 & $27(39)$ & $17(50)$ & 0 & $24(23)$ & $27(26)$ \\
\hline 1986 & $6(7)$ & 0 & $37(44)$ & $9(41)$ & 0 & $15(14)$ & $37(36)$ \\
\hline 1987 & $11(10)$ & 0 & $33(30)$ & $12(38)$ & 0 & $23(16)$ & $33(23)$ \\
\hline 1988 & $7(8)$ & 0 & $24(28)$ & $2(12)$ & 0 & $9(9)$ & $24(22)$ \\
\hline Mean & $7(8)$ & 0 & $27(36)$ & 9(33) & 0 & $16(15)$ & $27(25)$ \\
\hline
\end{tabular}

CXM, cefuroxime; VANC, vancomycin; GENT, gentamicin.

Table IV. Results of cefuroxime treatment for peritonitis episodes

\begin{tabular}{lcccc}
\hline & $\begin{array}{c}\text { Number (\%) of episodes } \\
\text { treated with } \geq 10 \\
\text { days cefuroxime }\end{array}$ & $\begin{array}{c}\text { Number (\%) of } \\
\text { treatment } \\
\text { failure episodes* }\end{array}$ & $\begin{array}{c}\text { Number (\%) of } \\
\text { strains resistant } \\
\text { to cefuroxime }\end{array}$ & $\begin{array}{c}\text { Number (\%) of } \\
\text { failure episodes } \\
\text { due to CNS }\end{array}$ \\
\hline 1983 & $53(66)$ & $12(23)$ & $3(6)$ & $8(67)$ \\
1984 & $67(71)$ & $28(42)$ & $9(13)$ & $14(50)$ \\
1985 & $61(59)$ & $20(33)$ & $6(10)$ & $11(55)$ \\
1986 & $50(48)$ & $19(38)$ & $2(4)$ & $16(84)$ \\
1987 & $80(58)$ & $26(33)$ & $2(3)$ & $18(69)$ \\
1988 & $62(59)$ & $27(44)$ & $3(5)$ & $20(75)$ \\
Mean & $62(60)$ & $22(35)$ & $4(7)$ & $15(67)$ \\
\hline
\end{tabular}

CNS, coagulase-negative staphylococci.

* Only patients receiving cefuroxime for $\geq 10$ days are included in treatment failure figures; for definition of treatment failure, see text; data available for $97 \%$ of episodes.

resistance was commoner among gram-negative species (mean 33\%, range $12-50 \%$ ); these included Pseudomonas spp. which were largely $(77 \%)$ and predictably resistant to cefuroxime; sensitive isolates were of species other than $P$. aeruginosa. Two Pseudomonas spp. isolates (4\%) only were resistant to ceftazidime. The cefuroxime resistance of grampositive isolates (mean $8 \%$, range $7-10 \%$ ) was low for CNS (mean 9\%, range 5-12\%) compared with resistance to gentamicin (mean $37 \%$, range $22-45 \%$ ).

Sixty percent of episodes of peritonitis were treated with cefuroxime for 10 days (table IV). In most of the remaining $40 \%$ cefuroxime was stopped early because of lack of response. Cefuroxime treatment failed clinically or microbiologically, or both, in $35 \%$ (range $23-44 \%$ ) of those receiving it for 10 days, despite an in-vitro resistance rate of only $7 \%$ (range $3-10 \%$ ); in $67 \%$ (range $50-84 \%$ ) of these treatment failures the infection was caused by CNS. In the cases where cefuroxime treatment failed, $18 \%$ of pathogens were resistant to this antibiotic. Vancomycin was successfully substituted for cefuroxime in $60(85 \%)$ of 71 episodes when the latter failed to cure infection caused by gram-positive species. 


\section{Discussion}

Despite more than a decade of experience, peritonitis remains the most serious and costly complication of CAPD. CAPD failure often follows recurrent episodes of peritonitis and sometimes peritonitis proves fatal. ${ }^{9}$ Few large renal units have examined prospectively their experience of CAPD-associated peritonitis, or have related treatment outcome to the antibiotic sensitivities of the responsible pathogens. ${ }^{10-12}$

Inter-unit comparison is difficult because of differing definitions and management of infections. In the present study all episodes of peritonitis, including those following immediately on insertion of the dialysis catheter, have been included. The culture failure rate fell from $15 \%$ to $5 \%$ (mean $10 \%$ ) reflecting current experience in other centres ${ }^{3}$ it is recognised in some instances that this results from antibiotic treatment being given before microbiological sampling. Most patients (mean $92 \%$, range $89-94 \%$ ) became infected at home; few needed hospital admission. The incidence of peritonitis improved from 2.0 to 1.2 episodes/ patient year during the 6 years of the study. While most centres report infection rates of 0.9-1.4 episodes/ patient year, some claim much lower rates. ${ }^{10-12}$ In our experience, the incidence of peritonitis fell following the phased introduction in late 1987 of the "Freeline Disconnect" system. ${ }^{13}$ This method, which involves flushing the tubing with dialysis fluid (initially away from the peritoneal cavity) at each exchange, and theoretically reduces the risk of bacterial contamination costs approximately $£ 1000$ more per patient year than the Luer-lock system II.

The number of episodes of peritonitis suffered by each patient per year varied widely from one to seven; $22 \%$ had at least three episodes. It is not known why some patients are at greater risk of developing peritonitis, but poor technique, equipment failure and impaired host defences have been suggested. ${ }^{12,14}$ Relapse may also be due to the persistent adherence of bacteria to plastic or peritoneal surfaces. ${ }^{15}$ The predominance of CNS as a cause of CAPD peritonitis may reflect their ability to adhere to prostheses, ${ }^{16}$ or may simply reflect their common presence in the normal fiora of the skin. Seventy-five percent of the CNS isolated during this study were $S$. epidermidis sensu strictu. This is similar to their preponderance in skin flora.

Although 26 different species of micro-organisms were isolated, six only caused more than $80 \%$ of all episodes of peritonitis (CNS, $S$. aureus, viridans streptococci, E. coli, Klebsiella spp. and Pseudomonas spp.). It is clear that a broad spectrum antibiotic or combined therapy should be used as first line treatment in CAPD peritonitis. ${ }^{3,17}$

In vitro, $85 \%$ of isolates were sensitive to cefuroxime whereas $73 \%$ of isolates were sensitive to gentamicin. However, each antibiotic has well-recognised limitations in its antimicrobial spectrum. Despite its extensive use in Nottingham for over 6 years, no increase in the percentage of strains resistant to cefuroxime has been detected. Indeed, more CNS isolates were resistant to gentamicin $(22-45 \%)$ than to cefuroxime (5-12\%). Pseudomonas spp. were predominantly resistant to cefuroxime $(77 \%)$; the strains sensitive to cefuroxime were of species other than $P$. aeruginosa. It is particularly encouraging that all grampositive and all gram-negative bacterial isolates were sensitive to vancomycin or gentamicin, respectively.

The failure of cefuroxime treatment given for 10 days to cure $35 \%$ of episodes of peritonitis when $7 \%$ only of the causal organisms were resistant in vitro to it is disappointing. The true failure rate may have been even higher because patients who were changed to alternative antibiotic regimens before 10 days treatment had been completed were not included in the analysis. The efficacy of cefuroxime was assessed after 10 days treatment had been given because this is the duration recommended in the CAPD Working Party Report. ${ }^{3}$ The decision to change treatment before 10 days was often made on clinical grounds in the absence of further microbiological data. Infections caused by CNS were over-represented $(67 \%)$ in the group in whom cefuroxime treatment failed, compared with their prevalence $(48 \%)$ in all episodes of peritonitis; this may reflect enhanced resistance in vivo of adherent bacteria. Such a phenomenon has been demonstrated in vitro for Pseudomonas spp. strains adherent to Tenchkoff catheter material. ${ }^{18}$ Antibiotic killing in peritoneal dialysis fluid is also slower than in conventional laboratory media. ${ }^{19}$ Gokal et al. have also reported a poor response to cefuroxime treatment. ${ }^{20}$ The failure rate in the present study for the period 1984-1988 $(38 \%)$ was significantly higher $(\mathrm{p}<$ $0.05)$ than in $1983(23 \%)$, when a higher dose of cefuroxime of $200 \mathrm{mg} / \mathrm{L}$ of dialysis fluid was given for 14 days.

All isolates were sensitive in vitro to either vancomycin or gentamicin; treatment of CAPD-associated peritonitis with a mixture of an aminoglycoside and a glycopeptide antibiotic has been successful. ${ }^{20}$ Vancomycin was effective in treating $85 \%$ of the episodes of peritonitis caused by gram-positive isolates that had failed to respond to cefuroxime. Although such alternatives to cefuroxime treatment are much more expensive, their greater efficacy and a consequent reduction in the number of antibiotic courses needed could begin to offset this difference. The results of controlled trials with newer agents such as ciprofloxacin, aztreonam and teicoplanin, which have potential for the treatment of CAPD-associated peritonitis, are awaited with interest.

In conclusion, during a 6-year-long prospective study, the predominance of CNS as a cause of CAPDassociated peritonitis has been confirmed, the microbiological detection rate increased, and the infection rate fell as the "Freeline Disconnect system" for dialysate exchange was introduced. ${ }^{13}$ Conventional antibiotic sensitivity testing proved a poor predictor 
of clinical outcome when cefuroxime was given as treatment; a more relevant sensitivity test system would be helpful. The high failure rate of cefuroxime as initial therapy, particularly for infections caused by CNS, suggests that alternative first-line regimens should be used to treat CAPD peritonitis.

\section{References}

1. Brunner FP, Broyer M, Brynger $\mathrm{H}$ et al. Combined report on regular dialysis and transplantation in Europe. XV. 1984. Proc Eur Dial Transpl Ass 1985; 22: 3-53.

2. Morgan AG, Burden RP. Effect of continuous ambulatory peritoneal dialysis on a British renal unit. $\mathrm{Br}$ Med J 1986; 293: 935-937.

3. Working Party of the British Society for Antimicrobial Chemotherapy. Diagnosis and management of peritonitis in continuous ambulatory peritoneal dialysis. Lancet 1987; 1: 845-849.

4. Greaves PW. New methods for the isolation of Legionella pneumophila. J Clin Pathol 1980; 33: 581-584.

5. Gould IM, Casewell MW. The laboratory diagnosis of peritonitis during continuous ambulatory peritoneal dialysis. $J$ Hosp Infect 1986; 7 : 155-160.

6. Cowan ST. Cowan and Steel's Manual for the identification of medical bacteria. London, Cambridge University Press. 1974.

7. Barry AL. The antimicrobic susceptibility test: principles and practices. Philadelphia, Lea and Febiger. 1976.

8. Stokes EJ, Waterworth PM. Antibiotic sensitivity tests by diffusion methods. Association of Clinical Pathologists Broadsheet No. 55 (revised) 1972.

9. Slingeneyer A, Mion C, Béraud JJ, Oulès R, Branger B, Balmers M. Peritonitis, a frequently lethal complication of intermittent and continuous ambulatory peritoneal dialysis. Proc Eur Dial Transpl Ass 1981; 18: 212-221.

10. Gokal R, Ramos JM, Francis DMA et al. Peritonitis in continuous ambulatory peritoneal dialysis. Laboratory and clinical studies. Lancet 1982; 2: 1388-1391.

11. Prowant B, Nolph K, Ryan L, Twardowski Z, Khanna R. Peritonitis in continuous ambulatory peritoneal dialysis:
The assistance of Mrs $\mathrm{K}$. Crompton and Mr J. Martin, the financial support of Roussell Laboratories and the excellent secretarial assistance of Mrs $\mathbf{M}$. Thompson are gratefully acknowledged.

analysis of an 8-year experience. Nephron 1986; 43: 105109.

12. Tranaeus A, Heimburger $O$, Lindholm B. Peritonitis during continuous ambulatory peritoneal dialysis (CAPD): risk factors, clinical severity, and pathogenetic aspects. Periton Dial Bull 1988; 8: 253-263.

13. Churchill DN, Lavoie S, Deveber GA et al. Peritonitis in continuous ambulatory peritoneal dialysis-a multi-centre randomized clinical trial comparing the Y-connector disinfectant system to standard systems. Periton Dial Int 1989; 9: $159-163$.

14. Verbrugh HA, Keane WF, Hoidal JR, Freiberg MR, Elliott GR, Peterson PK. Peritoneal macrophages and opsonins: antibacterial defence in patients undergoing chronic peritoneal dialysis. J Infect Dis 1983; 147: 1018-1029.

15. Holmes CJ, Evans R. Biofilm and foreign body infection-the significance to CAPD-associated peritonitis. Periton Dial Bull 1986; 6: 168-177.

16. Peters G. New considerations in the pathogenesis of coagulasenegative staphylococcal foreign body infections. $J$ Antimicrob Chemother 1988; 21; Suppl C: 139-148.

17. Keane WF, Everett ED, Fine RN, Golper TA, Peterson PK, Vas SI. CAPD related peritonitis-management and antibiotic therapy recommendations. Periton Dial Bull $1987 ; 7: 55-68$.

18. Craddock CF, Edwards R, Finch RG. Pseudomonas peritonitis in continuous ambulatory peritoneal dialysis: laboratory predictors of treatment failure. J Hosp Infect 1987; 10: 179186.

19. Wilcox MH, Edwards R, Finch RG. Laboratory studies on coagulase-negative staphylococci from CAPD-peritonitis. $J$ Antimicrob Chemother 1985; 15: 297-303.

20. Gokal R, Mistry CD, Monos J et al. Peritonitis in patients undergoing continuous ambulatory peritoneal dialysis. Netilmicin-a perspective of 5 years of clinical experience in UK. Franklin Scientific Publications. 1987: 24-27. 
